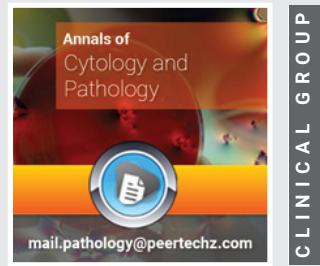

\title{
Mitotically active fibrothecoma in association with sclerous peritonitis
}

\author{
Bdioui Ahlem*, Ben Khlifa Sarra1, Kaabia Ons², Missaoui \\ Nabiha ${ }^{3}$, Hmissa Sihem ${ }^{4}$ and Mokni Moncef ${ }^{1}$ \\ 'Departement of pathology, Fathat Hached Hospital of Sousse, Tunisia \\ ${ }^{2}$ Departement of obstetric gynecology, Fathat Hached Hospital of Sousse, Tunisia \\ ${ }^{3}$ Research Unit 03/UR/08-13, Cancer Epidemiology and Cytopathology in Tunisian Centre, Medicine \\ Faculty, Sousse, Tunisia \\ ${ }^{4}$ Departement of pathology Sahloul Hospital of Sousse, Tunisia
}

Received: 24 February, 2020

Accepted: 20 April, 2020

Published: 21 April, 2020

*Corresponding author: Bdioui Ahlem, Departement of pathology, Fathat Hached Hospital of Sousse, Farhat Hached Hospital Street ibn Eljazzar, 4000 Sousse, Tunisia, Tel: 0021673223311; Fax: 0021673221411; E-mail: ahlembdioui@hotmail.com

Keywords: Ovarian tumor; Fibrothecoma; Sclerous peritonitis

https://www.peertechz.com

Check for updates

\section{Abstract}

Background: Mitotically active fibrothecoma associated with sclerosing peritonitis is an enigmatic and rare condition, described by Clement et al. in 1994 , with fewer than 50 pathologically characterized cases. Association of these two lesions is extremely rare and the etiology currently remains unclear; therefore, association with antiepileptic drugs was suggested.

Case presentation: We report the case of young female, with history of epilepsy, presented with acute severe abdomenal pain. Ultrasound revealed a $20 \mathrm{~cm}$ mass, possibly arised from ovary, which was associated with septate ascites. The microscopic examination of the mass showed a morphology fibrothecoma with areas of oedema and high mitotique index but without severe atypia.

Conclusion: Mitotically active fibrothecoma associated to sclerosing peritonitis is relatively rare condition. Although its disturbing presentation, the behavior of this rare condition is benign; therefore this entity should be well known by surgeon and pathologist to ovoid misdiagnosis and overtreatment of patient.

\section{Abbreviations}

hCG: human Chorionic Gonadotropin; CEA: CarcinoEmbryonic Antigen; CA-125: Cancer Antigen 125; CD56: Cluster de Différentiation 56; CK AE1/ AE3: Pan cytokeratin AE1/ AE3; CD34: Cluster de Différentiation 34; Ki-67: Proliferating Antigen Ki67

\section{Introduction}

Mitotically active fibrothecoma is recently described as a category of ovarian fibromatous tumors, defined by mitotic figures more than 4 per 10 high power fields, without moderate to severe atypia. Association with sclerosing peritonitis is an enigmatic and rare condition, first described in 1994 by Clement et al. with less than 50 pathologically characterized cases [1-3].

\section{Case report}

18-year-old woman with history of epilepsy, presented with severe acute abdominal pain. On physical examination, the abdomen was tender with a palpable mass in the left iliac fossea. Ultrasound revealed a $20-\mathrm{cm}$ heterogeneous left pelvic mass as well as free peritoneal fluid. The right ovary and the uterus appeared normal.

Serum analysis revealed that the Human Chorionic Gonadotropin (hCG) test was negative and serum levels of Carcinoembryonic Antigen (CEA) and Cancer Antigen 125 (CA125) were normal. The patient underwent laparotomy which showed large left ovarian tumor, associated with sclerosing ascites.

The right ovary, fallopian tubes, and uterus were 
unremarkable. Left salpingo-oophorectomy and intraoperative biopsy of the right ovary were performed.

On gross examination, the outer surface of the left ovary appeared lobulated, measuring $16 \mathrm{~cm}$ across its largest diameter (Figure 1). The yellowish sectioned surfaces of the ovarian mass were solid with edematous areas.

Microscopically, the tumor showed variable cellularity (Figure 2) with hypercellular zones alternating with hypocellular foci (Figure 3), it was comprised of fascicles and sheets of plump monomorphous spindle and oval cells, with no atypia. Patchy area of edema was noted. Within the spindle cell population, lutein-like cells were scattered singly or in clusters. Mitotic counts of spindle cells revealed 15 mitotic figures per 10 high-power fields (Figure 4). The right ovarian biopsy was histologically normal.

At immunohistochemestry, tumors cells expressed focally calretin (Figure 5) and inhibin (Figure 6). The proliferated antigen Ki67 was estimated at 20\% (Figure 7).

Thus, diagnosis of unilateral mitotically active fibrothecoma associated to sclerosing ascitis was made.

The patient was discharged 7 days later. The clinical outcome was uneven, within 8 months of follow up.

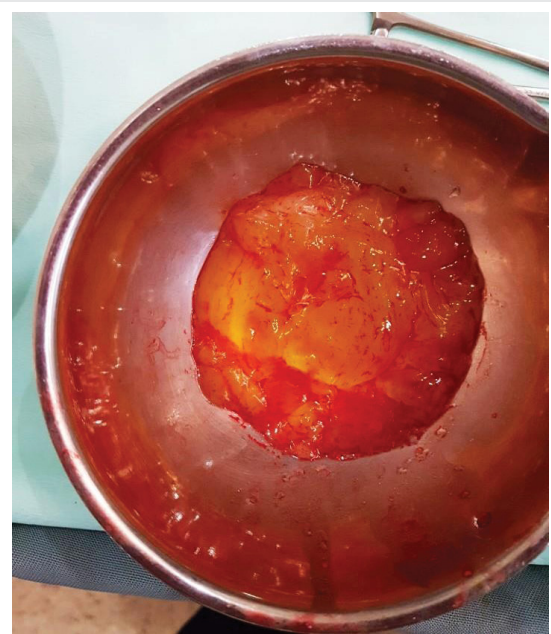

Figure 1: Surgical specimen of the ovarian tumor.

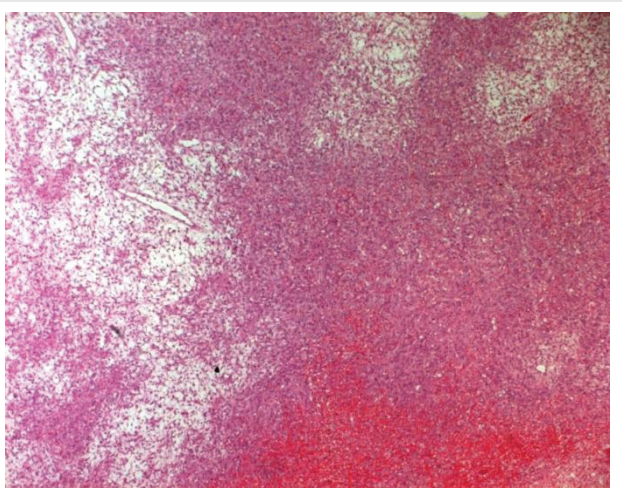

Figure 2: Tumor with variable cellularity with area of edema and haemorrhage (HE $x$ 40).

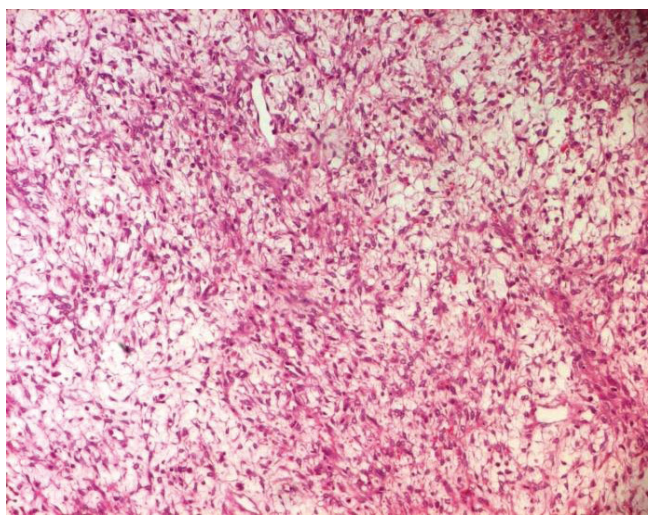

Figure 3: Hypocellular area, presence of luteinized cells (HE x 100)

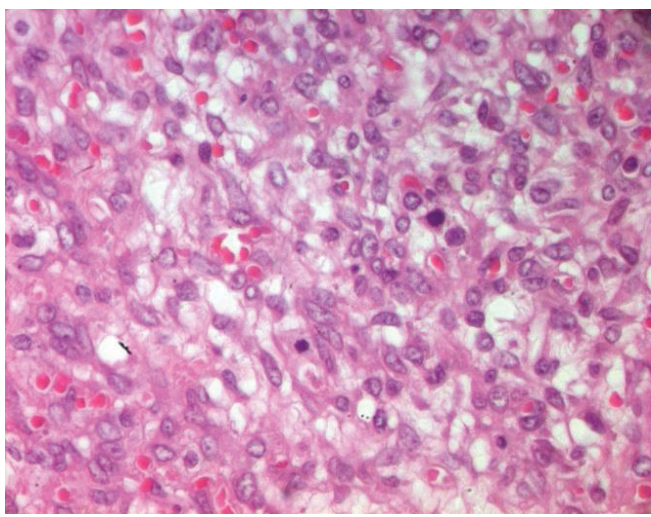

Figure 4: Mitotically active monomorphous spindle and oval cells, with no atypia (HE x 400).

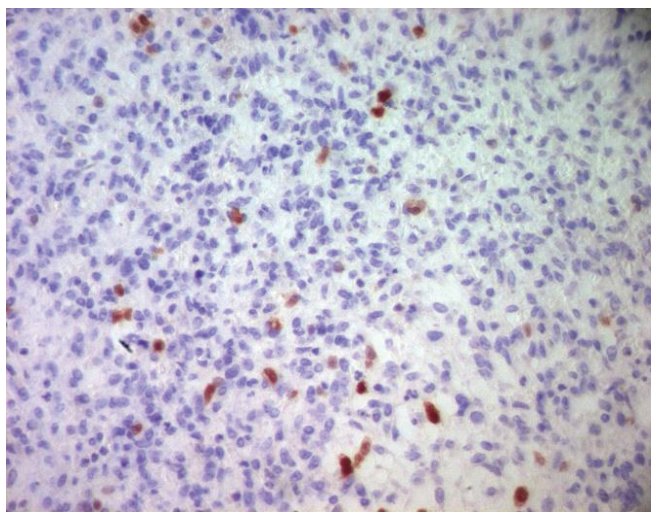

Figure 5: Focal expression of Claritin (IHC x 200)

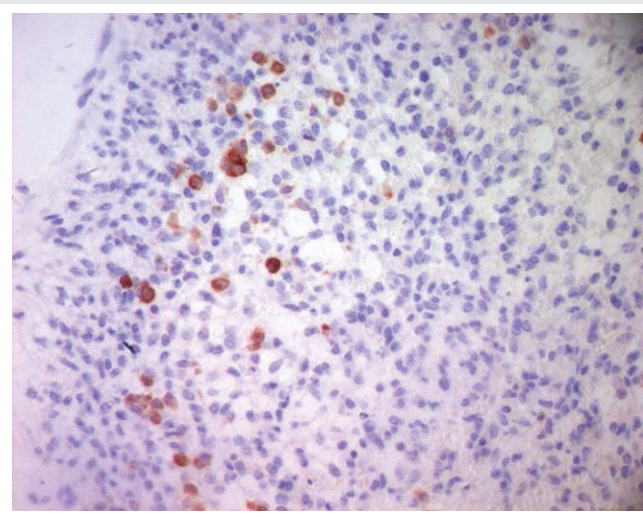

Figure 6: Focal expression of Inhibin (IHC x 200).

Citation: Ahlem B, Sarra BK, Ons K, Nabiha M, Sihem H, et al. (2020) Mitotically active fibrothecoma in association with sclerous peritonitis. Ann Cytol Pathol 5(1) 044-047. DOI: https://dx.doi.org/10.17352/acp.000014 


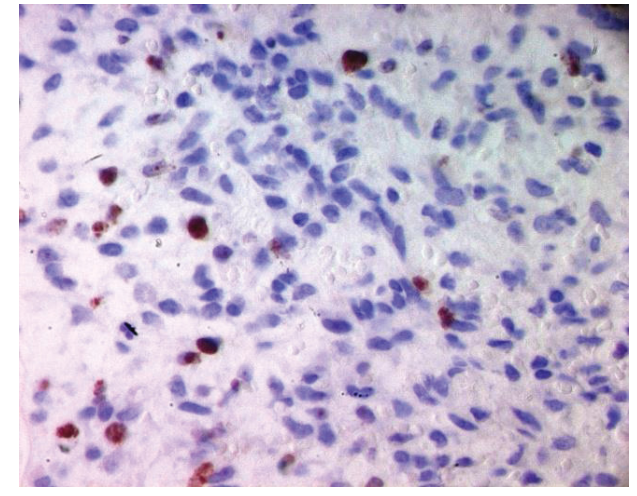

Figure 7: Ki-67 proliferating Antigen (IHC x 400)

\section{Discussion}

Mitotically active fibrothecoma is a recently described category of ovarian stromal tumors, representing less than $10 \%$ of fibrothecoma.This entity is defined by mitotic figures more than 4 per 10 high power fields, without moderate or severe atypia $[4,5]$.

The median age of patient is 41 year and most frequent symptoms are abdominal mass, acute pain, ascites as in our case with dysfunctional uterine bleeding [6].

Biologically, two cases are reported in the literature with a high level of CA125 [6].

In gross, the tumor appears as a large ovarian mass, has well-defined capsule and the cut-surface showed typical yellow bosselated appearance.

The average size has been reported to be $9.4 \mathrm{~cm} \mathrm{[6].}$ Microscopically, the tumor is hypercellular, usually with area of edema, occasionally imparting a microcystic appearance. Most of the tumor cells are spindle but a minority was round with pale cytoplasm, representing weakly luteinized cells.

The median mitosis was found to be 6 , with a maximum of 19 mitosis under 10 high power fields. Historically, since 1981, as described by Pratt and Scully, the 4 mitotic activities of the cells was given equal importance as nuclear atypia in predicting the aggressiveness of an ovarian fibromatous tumour and classifying as fibrosarcoma. The tumour which exhibit a mitotic activity of $\leq 3 / 10$ HPF is labelled fibromas, while those with $\geq 4 / 10$ HPF mitotic figure were considered malignant in nature [4,7-9].

As time elapsed and more cases were reported, tumours that had high mitotic counts of $\geq 4 / 10 \mathrm{HPF}$ but minimal nuclear atypia were found to be less aggressive and followed a more indolent clinical course. Hence in 2006, Irving et al. proposed the reclassification of fibromatous tumours, introducing mitotically active fibrothecoma for the first time, which fitted into the afore-mentioned criteria. This has been included in the WHO histological classification since 2014 [4,7-9].

Immunohistochemical studies have shown that the tumor cells to be reactive with calretinin, Cluster of differentiation
56(CD56), Pan Cytokeratin AE1/ AE3, smooth muscle actin desmin and variably with alpha inhibin, epithelial membrane antigen, beta-catenin, CD34, and transforming growth factorbeta with focal nuclear positivity for estrogen and progesterone receptors [3].

In rare cases, as the case of our patient, fibrothecoma may be associated with sclerosing peritonitis. The etiology and pathogenesis of this association is not clear; but a relation with anti-epileptic drug has been discussed. Our case consolidate this hypothisis, since our patient, as the case reported by Pati et al, was under anti epilepsy drug [3,10].

On the other hand, some author proposed fibrosing soluble cytokines secreted by tumor cells to be responsible for the peritoneal manifestations [3]

Microscopically, the process of peritonitis consists of fibroblastic and myofibroblastic cell proliferation separated by collagen and fibrin, mesothelial cell proliferation, and occasionally mononuclear inflammatory cells [3].

Currently, the concept is that the tumor is benign in behavior although complications due to sclerosing peritonitis bring down the quality of life [3].

No standard treatment for mitotically fibrothecoma currently exists, although overtreatment should be avoided in women requiring preservation of fecundity. Zong et al. suggested that other risk factors, such as tumor size, growth rate and the evaluation of $\mathrm{Ki}-67$, should be considered $[6,11]$.

\section{Conclusion}

Mitotically active fibrothecoma associated to sclerosing peritonitis is relatively rare condition. Although its disturbing presentation with a large tumor size, higher mitotic index and peritoneal involvment, the behavior of this rare condition is benign; therefore this entity should be well known by surgeon and pathologist to ovoid misdiagnosis and overtreatment of patient. Standard guideline of treatment is yet to be formulated for this entity.

The authors declare that there are no conflicts of interest associated with this manuscript.

\section{References}

1. Clement PB, Young RH, Hanna W, Scully RE (1994) Sclerosing peritonitis associated with luteinized thecomas of the ovary: a clinicopathological analysis of six cases. Am J Surg Pathol 18:1-13. Link: https://bit.ly/2ypCN5o

2. Staats $P, M c C l u g g a g e ~ W G, C l e m e n t P B, Y o u n g ~ R H ~(2008)$ Luteinized Thecomas Typically Associated with Sclerosing Peritonitis A Clinical, Histopathologic and Immunohistochemical Analysis of 27 Cases. Am J Surg Pathol 32: 12731290. Link: https://bit.ly/2VIJz4T

3. Pati A, Mukhopadhyay S, Nandi A, Das I (2017) Sclerosing peritonitis with unilateral ovarian luteinized thecoma in a post-menopausal woman: A case report J Midlife Health 5: 198-201. Link: https://bit.ly/2xAdxJH

4. Kulkarnia R, Bhata R, Dhakhariaa V, Gangolib A, Sharmab K (2017) Mitotically active cellular fibroma of the ovary: a rare case and review of literature. Southern African Journal of Gynaecological Oncology 9:19-21. Link: https://bit.ly/2RSXnS 
5. Yamada T, Hattori K, Satomi H, Hirose $Y$ (2015) Mitotically active cellular fibroma of the ovary: a case report and literature review. Journal of ovarian Research. Link: https://bit.ly/2VHuvh3

6. Yildirim N, Saatli B, Akalin F, Ulukus C, Obuz F, et al. (2015) Mitotically active cellular fibroma of the ovary: a case report Turk Soc Obster Gynecol 1: 53-55. Link: https://bit.ly/2wSOQrr

7. Prat J, Scully RE (1981) Cellular fibromas and fibrosarcomas of the ovary: a comparative clinicopathologic analysis of seventeen cases. Cancer 47: 26632670. Link: https://bit.ly/2xIXNnA

8. Matsuda K, Tateishi S, Akazawa Y, Kinoshita A, Yoshida S, et al. (2016) Rapid growth of mitotically active cellular fibroma of the ovary: a case report and review of the literature. Diagn Pathol 11:101. Link: https://bit.ly/2xluBNt
9. Mellembakken JR, Engh V, Tanbo T, Czernobilsky B, Edelstein E, et al (2010) Mitotically active cellular luteinized thecoma of the ovary and luteinized thecomatosis associated with sclerosing peritonitis: Case studies, comparison, and review of the literature. Pathol Res Pract 206: 744-774. Link: https://bit.ly/3csLvOI

10. Iwa Y, Mlnamlguchl S, Konishi I, OnderaJH, Zhou J, et al. (1996) Sclerosing peritonitis associated with luteinized thecoma of the ovary. Pathol Int 46: 510514. Link: https://bit.ly/2XKQo1।

11. Zong L, Lin M, Fan X (2014) Mitotically active cellular fibroma of ovary should be differentiated from fibrosarcoma: a case report and review of literature. Int J Clin Exp Pathol 7: 7578-7758. Link: https://bit.ly/2RSK2td

\section{Discover a bigger Impact and Visibility of your article publication with} Peertechz Publications

\section{Highlights}

* Signatory publisher of ORCID

* Signatory Publisher of DORA (San Francisco Declaration on Research Assessment)

* Articles archived in worlds' renowned service providers such as Portico, CNKI, AGRIS, TDNet, Base (Bielefeld University Library), CrossRef, Scilit, J-Gate etc.

* Journals indexed in ICMJE, SHERPA/ROMEO, Google Scholar etc.

* OAI-PMH (Open Archives Initiative Protocol for Metadata Harvesting)

- Dedicated Editorial Board for every journa

* Accurate and rapid peer-review proces

- Increased citations of published articles through promotions

* Reduced timeline for article publication

Submit your articles and experience a new surge in publication services (https://www.peertechz.com/submission).

Peertechz journals wishes everlasting success in your every endeavours.

Copyright: @ 2020 Ahlem B, et al. This is an open-access article distributed under the terms of the Creative Commons Attribution License, which permits unrestricted use distribution, and reproduction in any medium, provided the original author and source are credited. 